\title{
Trump Döneminde Diplomatik Aktör Olarak Çevirmenler
}

\author{
Interpreters as Diplomatic Actors in the Trump Era
}

\section{Seçkin Barış GÜLMEZ}

Dr. Öğr. Üyesi, İzmir Katip Çelebi Üniversitesi, Uluslararası İlişkiler Bölümü

\section{Nihal YETKÍN KARAKOÇ}

Doç. Dr., İzmir Ekonomi Üniversitesi, Mütercim Tercümanlık Bölümü

\section{Didem BUHARİ GÜLMEZ}

Doç. Dr., İzmir Katip Çelebi Üniversitesi, Uluslararası İlişkiler Bölümü

\section{Bu makaleye atıf için}

Seçkin Barıș Gülmez; Nihal Yetkin Karakoç ve Didem Buhari Gülmez, "Trump Döneminde Diplomatik Aktör Olarak Çevirmenler", Uluslararası İişkiler, Cilt 17, Sayı 65, 2020, s. 63-82, DOI: $10.33458 /$ uidergisi.655130

Makaleye Erişim İçin: https://dx.doi.org/10.33458/uidergisi.655130

Makale Gönderim: 05 Mayis 2019

Son Düzeltme: 29 Ekim 2019

İnternet Yayım: 13 Aralık 2019

Basım Tarihi: 01 Mart 2020

\section{Uluslararası İlişkiler Konseyi Derneği | Uluslararası İlişkiler E-Posta: bilgi@uidergisi.com.tr}

Bu makalenin tüm hakları Uluslararası İişkiler Konseyi Derneğìne aittir. Önceden yazılı izin almadan hiçbir iletişim, kopyalama ya da yayın sistemi kullanılarak yeniden yayımlanamaz, çoğaltılamaz, dağıtılamaz, satılamaz veya herhangi bir ssekilde kamunun ücretli/ücretsiz kullanımına sunulamaz. Akademik amaçlı alıntılar bu kuralın dışındadır. Yazıda belirtilen fikirler yalnızca yazarına/yazarlarına aittir. UİK Derneğini, editörleri ve diğer yazarları bağlamaz. 


\title{
Trump Döneminde Diplomatik Aktör Olarak Çevirmenler
}

\author{
Seçkin Barış GÜLMEZ \\ Dr. Öğr. Üyesi, İzmir Katip Çelebi Üniversitesi, Uluslararası İlişkiler Bölümü, İzmir \\ E-posta: seckinbaris.gulmez@ikc.edu.tr \\ Nihal YETKIN KARAKOÇ \\ Doç. Dr., İzmir Ekonomi Üniversitesi, Mütercim Tercümanlı (İngilizce) Bölümü, İzmir \\ E-posta:nihal.yetkin@ieu.edu.tr \\ Didem BUHARİ GÜLMEZ \\ Doç. Dr. İzmir Katip Çelebi Üniversitesi, Uluslararası İlişkiler Bölümü, İzmir \\ E-posta: mdidem.buhari.gulmez@ikc.edu.tr
}

\section{ÖZET}

Bu çalışmanın amacı Trump döneminde çevirmenlerin diplomasi karşıtlığı geleneğiyle anılan ABD dış politikasına etkilerini araştırmaktır. Uluslararası İlişkiler ve Çeviribilim literatürlerinde çevirmenlerin etki alanı çok dar bir çerçevede tartışılmış ve çevirmenler bir aktör olarak görülmemiştir. Bu bağlamda, çevirmenlerin Trump döneminde diplomasi dili, teamülleri ve aktörleri açısından oluşan boşluğu doldurmaya yönelik girişimleri incelenecektir. Makalenin ilk bölümünde çevirmenlerin ve diplomatların işlevleri karşılaştırıldıktan sonra ikinci bölümde çevirmenlerin diplomasiye etkileri iletişim filtresi ve uzlaştırma olmak üzere iki ana başlık altında incelenecektir. Çevirmenler, iletişim filtresi olarak zaman kazandırma, moderatörlük ve eşik bekçisi rollerini üstlenirken, uzlaştırma kapsamında günah keçisi, kriz önleyici ve arabulucu olarak diplomatik süreçleri etkilemektedirler. Uluslararası İlişkiler ve Çeviribilim disiplinleri arasında bağlantı kurarak çevirmenlerin varsayılandan çok daha geniş bir etki alanı olduğunu gösteren bu çalışma, çevirmenlerin önemli bir diplomatik aktör olarak ele alınıp alınamayacağı tartışmasına yön veren öncü çalışmalar arasında yer almayı hedeflemektedir.

Anahtar Kelimeler: Diplomat, Diplomasi Karşıtlığı, Çevirmen, ABD, Trump

\section{Interpreters as Diplomatic Actors in the Trump Era}

\begin{abstract}
This article investigates the impact of interpreters on the US foreign policy that is defined with a tradition of antidiplomacy in the Trump era. The literature in both International Relations and Translation Studies often overlooks the impact of interpreters on diplomacy and fails to consider interpreter as an actor per se. In this context, the study will investigate the initiatives undertaken by interpreters in order to fill the emerging gap in the diplomatic sphere in terms of diplomatic language, customs and actors in the Trump era. Accordingly, the article first comparatively examines the role of interpreters and diplomats and then, discusses the key roles of interpreters in diplomacy under two main categories: "communication filter" involving time-gaining strategy, moderation and gatekeeping and "conciliation" that includes the roles of scape goat, crisis prevention and mediation. Overall, this study demonstrates that interpreters have a greater space of manoeuvre than is generally assumed in terms of influencing diplomatic processes. By establishing the missing link between International Relations and Translation Studies, this study aims to become a pioneering work that contributes to the debate about whether interpreters can be considered as an important diplomatic actor.
\end{abstract}

Keywords: Diplomat, Anti-diplomacy, Interpreter, US, Trump 


\section{Giriş}

$\mathrm{Bu}$ çalışma, "çevirmenler diplomasiye etki edebilir mi?" sorusuna yanıt aramak için Trump dönemi Amerikan diplomasisine odaklanmaktadır. Dış politika analizi literatürü siyasi liderlere, üst düzey bürokratlara, danışmanlara, askerlere, diplomatlara ve bilim insanlarına odaklanmakta ve çevirmenlerin dış politikaya ve diplomasi kurumuna etkisini genellikle göz ardı etmektedir. ${ }^{1}$ Diplomasi literatüründe de çevirmenlerin diplomaside oynadıkları rol çoğu zaman göz ardı edilmekte ve yalnızca Satow gibi hem çevirmenlik hem de diplomatlık görevinde bulunmuş şahsiyetlerin biyografik incelemesi ön plana çıkmaktadır. ${ }^{2}$ Dolayısıyla, diplomasi literatüründe çevirmenlere yönelik kapsamlı bir çalışma eksikliği olduğu söylenebilir. Çeviribilim literatürüne bakıldığında çevirmenlerin diplomaside etkin olma potansiyeli kabul edilmekle beraber bu etkinliğin görev ihlali oluşturacağı vurgulanmaktadır. ${ }^{3}$ Çeviribilim literatürü de çevirmenlerin diplomasiye nasıl müdahil olduklarını veya olabileceklerini irdelemekten kaçınmaktadır. Bunun en önemli sebebi, çevirmenin aktörden ziyade, pasif bir aktaran olduğu varsayımıdır. ${ }^{4}$

Bu çalışma, akademik literatürdeki açığı gidermeyi amaçlamaktadır. Bunun için diplomatların ve diplomasi teamüllerinin geri planda kaldığı son dönem ABD dış politikasını mercek altına alarak çevirmenlerin $\mathrm{ABD}$ diplomasisine etkilerini tartışmaktadır. Diplomasinin ABD yönetimlerince geri planda tutulması durumu Trump dönemine özgü değildir. Kuruluşundan bu yana ABD, Avrupa merkezli olan diplomasi geleneğine mesafeli yaklaşmakta ve müzakerelerde karar vericilerin ön plana çıktığı, literatürde "diplomasi karşıtlı̆̆ı" (anti-diplomacy) adı verilen dış politika pratiğini benimsemektedir. İlgili literatüre önemli katkıda bulunan Wiseman'a göre ${ }^{5}$, ABD’nin izlediği diplomasi karşıtı uygulamasını alışılagelmiş diplomasi pratiklerinden farklı kılan yedi temel özellik bulunmaktadır. Bunlardan ilki, diplomasi ve diplomatlara karşı duyulan tarihsel güvensizliktir. ABD’nin yalnızcılık (isolationism) politikasının bir yansıması olarak da okunabilecek bu yaklaşıma göre, diplomasi ve diplomatlar eski sömürgecilik düzeninin temsilcisi veya uzantısı olarak değerlendirilerek uzun süre reddedilmiştir. ${ }^{6}$ Öyle ki, ABD ilk daimi büyükelçisini Londra’ya 1893 yılında, yani bağımsızlık bildirgesini imzaladıktan tam 117 yıl sonra göndermiştir. ${ }^{7}$

ABD’yi diplomasi karşıtlığına yönelten ikinci etmen, ABD’de iç siyasetin dış politikaya ve diplomasiye olan güçlü etkisidir. Amerikan siyasi kültürüne göre, seçilmiş siyasetçiler atanmış

1 Margaret G. Hermann, Thomas Preston, Baghat Korany ve Timothy M. Shaw, "Who Leads Matters: The Effects of Powerful Individuals”, International Studies Review, Cilt 3, No 2, 2001, s. 83-131; Morton H. Halperin, Priscilla A. Clapp ve Arnold Kanter, Bureaucratic Politics and Foreign Policy, 2. Baskı, Washington, The Brookings Institution, 2006; Julia M. MacDonald, "Eisenhower's Scientists: Policy Entrepreneurs and the Test-Ban Debate 1954-1958”, Foreign Policy Analysis, Cilt 11, No 1, 2015, s.1-21; Seçkin B. Gülmez, "Do Diplomats Matter in Foreign Policy? Sir Percy Loraine and the Turkish-British Rapprochement in the 1930s", Foreign Policy Analysis, Cilt 15, No 1, 2019, s. 65-82.

2 Ruth Ailene Roland, Interpreters as Diplomats, A Diplomatic History of the Role of Interpreters in World Politics, Ottawa, University of Ottawa Press, 1999; Brian Harris, “Ernest Satow's Early Career as Diplomatic Interpreter”, Diplomacy \& Statecraft, Cilt 13, No 2, 2002, s.126-127.

3 Alev K. Bulut, Tercüme Hatası!?, İstanbul, Çeviri Yayınları, 2015.

4 Cecilia Wadensjö, Interpreting as Interaction, Londra ve New York, Longman, 1998.

5 Geoffrey Wiseman,"Distinctive Characteristics of American Diplomacy”, The Hague Journal of Diplomacy, Cilt 6, No 3, 2011, s. 238.

6 Geoffrey Wiseman, "Pax Americana: Bumping into Diplomatic Culture”, International Studies Perspectives, Cilt 6, No 4, 2005, s. 415; Wiseman "'Distinctive Characteristics", s. 239-240.

7 Wiseman ,"Distinctive Characteristics”, s. 239. 
diplomatlardan çok daha önemli ve etkilidir. ${ }^{8}$ ABD Başkanının ulusal güvenlik danışmanlığını yapan Henry Kissinger ve Zbigniew Brzezinski gibi siyaseten önemli isimler, diplomatları işleri yavaşlatmakla, hatta güvenilmez ve gereksiz olmakla suçlayarak kritik müzakerelerde ABD Dışişleri Bakanlığını sıklıkla devre dışı bırakmayı tercih etmişlerdir.9

Üçüncü etmen, $A B D$ 'nin geleneksel olarak dış politikada sert gücü yumuşak güce tercih etme eğilimidir. ${ }^{10}$ ABD'nin diplomasi faaliyetlerinde askeri gücünü rakibine karşı caydırıcı bir etmen olarak ön plana çıkarması Amerikan diplomasisinin "ordu devleti" (garrison state) ve "savaşan devlet" (warrior state) gibi kavramlarla anılmasına neden olmaktadır. ${ }^{11}$ Dördüncü etmen, ABD’nin çok taraflı diplomasiden ziyade ikili diplomasiyi benimsemesi ve Birleşmiş Milletler (BM) gibi çok taraflı kuruluşlara karşı önyargılı olmasıdır. ${ }^{12}$ BM karşıtı söylemleriyle tanınan John Bolton'un 2005 yılında ABD’nin BM nezdindeki Büyükelçisi olarak atanması bu önyargının devam ettiğini göstermektedir. ${ }^{13}$ Beşinci etmen olarak Wiseman, ABD'nin düşman olarak gördüğü hiçbir ülkeyle diplomatik diyaloğa girmeyerek o ülkeleri dünyada yalnızlaştırma eğilimini vurgular. ${ }^{14}$

Altıncı etmen, ABD'de Büyükelçilerin önemli bir kısmının siyasi atama yoluyla göreve gelmesidir. ${ }^{15}$ Geleneksel olarak, ABD Büyükelçilerinin ortalama \%70’i kariyer diplomatıyken, \%30 kadarı Başkan tarafından siyaseten atanmaktadır. ${ }^{16} \mathrm{Bu}$ oran Obama döneminde \%64'e \%36 iken, Trump döneminde boş kalmış mevkiiler de hesaba katıldı̆̆ında, siyaseten atananların oranı neredeyse \%50'ye çıkmıştır. ${ }^{17}$ Yedinci etmen, Amerikan dış politika kültüründe diplomatlar aracıllı̆ıyla yürütülen uzun vadeli ve ortak çıkarlar inşa etmeye dayalı işbirliği ve diyalog yerine devlet insanları tarafından doğrudan yürütülen kısa sürede sonuç almaya yönelik müzakerelerin tercih edilmesidir. ${ }^{18}$

Wiseman ${ }^{19}$ bu yedi etmenden ötürü ABD'nin diplomasi anlayışının Avrupa diplomasisiyle uyuşmadığını ve Avrupa diplomasi geleneğine karşı ABD’nin diplomasi karşıtı uygulamaları ön plana çıkardığını belirtmektedir. ABD, Körfez savaşları da dahil olmak üzere birçok dış politika meselesinde tek taraflı kuvvet kullanımını diplomasinin önünde tuttuğundan, Wiseman ${ }^{20}$ ABD'nin hiçbir zaman tam anlamıyla uluslararası diplomatik sistemin içinde yer almadığını savunmaktadır. ABD’deki geleneksel diplomasi karşıtı eğiliminin yanısıra, küreselleşmeden kaynaklanan siyasi, ekonomik ve sosyal krizlere tepki olarak dünyada yükselen "güçlü devlet adamı siyaseti” (strongman politics) ve

8 Ibid., s. 242.

9 Geoffrey R. Berridge, Maurice Keens-Soper ve Thomas G. Otte (der.) Diplomatic Theory from Machiavelli to Kissinger, Basingstoke, Palgrave, 2001, s. 38; Christer Jönsson ve Martin Hall, "Communication: An Essential Aspect of Diplomacy”, International Studies Perspectives, Cilt 4, No 2, 2003, s. 198.

10 Wiseman "Distinctive Characteristics", s. 245.

11 Ibid., s. 246.

12 Ibid., s. 248.

13 Ibid., s. 249.

14 Ibid., s. 251.

15 Ibid., s. 253.

16 Ibid.

17 AFSA, “Tracker: Current U.S. Ambassadors”, American Foreign Service Association, 22 Ağustos 2019, http://www. afsa.org/list-ambassadorial-appointments (Erişim Tarihi 5 Eylül 2019).

18 Ibid., s. 255.

19 Ibid., s. 238.

20 Wiseman, "Pax Americana”, s.415. 
“devlet idaresi” (statecraft) ${ }^{21}$ akımları, ABD’li yöneticilerde diplomasi dili, kurumları ve aktörlerini geri plana itme eğilimini daha da artırmıştır.

Diplomasi pratiğini gölgede bırakma eğilimi özellikle Donald Trump’n ABD Başkanlığı döneminde belirgin ve sistematik hale gelmiştir. Trump dönemi salt diplomasi dilinin değil, aynı zamanda diplomatların etkinliğini ciddi anlamda yitirmeye başladığı bir dönemdir. Bu nedenle diplomasi alanında önemli bir güç boşluğu oluştuğu görülmektedir. Trump temel olarak iki şekilde diplomasi bürokrasisini devre dışı bırakma yoluna gitmektedir. Birincisi, aktif olarak kullandığı sosyal medya hesabından diğer ülke liderlerine yönelik diplomatik dile uygun olmayan sert mesajlar yazarak uluslararası krizlere yol açmaktadır. Örneğin, yasadışı göçü engellemek için Meksika sınırına duvar öreceğini ve duvarın maliyetini Meksika hükümetine ödetmek istediğini Twitter aracılığıyla ilan ederek iki devlet arasındaki ilişkileri germiş ve ABD’nin Meksika Büyükelçisinin istifasına neden olmuştur. ${ }^{22}$ Ayrıca, Trump terör suçlamasıyla Türkiye'de tutuklu bulunan ABD vatandaşı Rahip Andrew Brunson'un serbest bırakılması için Türk hükümetini ekonomik yaptırımla tehdit eden "tweetler” atarak ABD Dışişleri Bakanlığı'nı devre dışı bırakmış ve ABD-Türkiye ilişkilerini ciddi bir krize sürüklemiştir. ${ }^{23}$

İkinci olarak, Trump ABD’nin geleneksel Batı ittifakındaki yerini açıkça sorgulamaya başlamış ve ABD Dışişleri tarafından güvenlik tehdidi yarattığı düşünülen devletlerin liderleriyle yaptığı gizli görüşmelere ABD’li diplomatları dahil etmemiştir. Trump’ın Rusya Devlet Başkanı ve Kuzey Kore lideriyle yaptığı ikili görüşmelere çevirmen dışında hiçbir ABD'li görevli alınmamıştır. Üstelik 20'den fazla Dışişleri ve Beyaz Saray mensubu Trump'ın dış politika vizyonuna uyum sağlayamadıkları gerekçesiyle Trump tarafından bizzat görevden alınmışı̧ır ${ }^{24}$. Ayrıca, Trump döneminde ABD Dışişleri Bakanlığı bünyesinde görev yapan çok sayıda diplomat görevinden istifa etmiştir. İstifa edenler arasında ABD’nin BM nezdinde Büyükelçisi Nikki Haley, ABD’nin Meksika Büyükelçisi Roberta Jacobson ve ABD’nin Panama Büyükelçisi John Feeley gibi üst düzey bürokratlar da bulunmaktadır. ${ }^{25}$ Diplomatlar istifa mektuplarında ABD Dışişleri kurumunun siyaset üstü yapısının ortadan kaldırıldığını ve Amerikan çıkar ve değerlerini yurtdışında savunamayacak duruma düştüklerini açıklamışlardır. ${ }^{26}$ Eylül 2019 itibariyle, ABD’nin yurtdışındaki 188 Büyükelçiliğinden 57'si Büyükelçi olmadan görev yapmaktadır. ${ }^{27}$

Trump'ın, Dışş̧leri kurumunu yok sayması, diplomasinin yürütülmesi açısından önemli bir boşluğa neden olmaktadır. ABD dış politikasının istikrarı için bu diplomatik boşluğun nasıl dolacağı sorusu ortaya çıkmaktadır. Bu çalışma, siyasi liderlerin özellikle uluslararası arenada dil

21 Devlet İdaresi kavramı liderlerin dış politika hedeflerine ulaşmak amacıyla diğer devletlerin politikalarını değiştirmeye yönelik attığı adımlar olarak tanımlanmaktadır. Bknz. Kalevi Holsti, “The Study of Diplomacy”, James N. Rosenau, Kenneth W. Thompson ve Gavin Bond (der.), World Politics: An introduction, New York, Free Press, 1976, s. 293-311; Stacie E Goddard, Paul K MacDonald ve Daniel H Nexon, "Repertoires of statecraft: instruments and logics of power politics”, International Relations, Cilt 33, No 2, 2019, s. 304-321.

22 "U.S. Ambassador to Mexico to Quit Amid Tense Relations Under Trump", The New York Times, 1 Mart 2018.

23 Laura Koran, “Trump threatens to sanction Turkey if they don't release US pastor”, CNN, 26 Temmuz 2018.

24 Görevlerinden alınanlar arasında Dışişleri Bakanı Rex Tillerson, Dışişleri Bakanlığı Kamu Diplomasi Müsteşarı Steve Goldstein ve FBI Başkanı James Comey de bulunmaktadır. Bkz. Sam Morris ve Francisco Navas, "The firings and fury: The biggest Trump resignations and firings so far", The Guardian, 5 Temmuz 2018.

25 Morris ve Navas, "The firings and fury".

26 Dan De Luce ve Robbie Gramer, “U.S. Diplomat’s Resignation Signals Wider Exodus From State Department”, Foreign Policy, 9 Aralık 2017.

27 AFSA, “Tracker: Current U.S. Ambassadors”. 
engeline takıldıkları için bu boşluğu tek başlarına dolduramadıklarını, dolayısıyla diplomatik çevirmenlerin diplomaside daha geniş etki alanı kazandığını vurgulamaktadır. Trump gibi "güçlü adam siyasetinin" temsilcileri, diplomatları potansiyel rakip olarak görebilirken çevirmenlere aynı şekilde yaklaşmamaktadır. Ne de olsa çevirmen, liderin uluslararası alanda ana dilini kullanmasını sağlayarak milli kimliği koruma bağlamında lidere meşruiyet sağlar. ${ }^{28}$ Ayrıca, Trump’ın Rusya ve Kuzey Kore liderleriyle yaptığı kritik ikili görüşmelere yalnızca diplomatik çevirmeniyle katılması, çevirmenin "sırdaş" (confidant) olma rolünü öne çıarır.

ABD’nin Soğuk Savaş döneminde geliştirdiği “kamu diplomasisi”"29 de, Amerikan diplomasi karşıtı anlayışının bir uzantısı olarak, Avrupa tipi diplomasiye önemli bir alternatif getirmiştir. ${ }^{30}$ Kamu diplomasisi literatürü son yıllarda alanın en dikkat çeken unsurlarından biri olmuştur. $\mathrm{Ne}$ var ki, çevirmenlerin dolaylı veya doğrudan yaptığı müdahalelerle liderlerin uluslararası kamuoyu nezdindeki imajına yönelik olumlu ya da olumsuz etkileri, kamu diplomasi literatüründe göz ardı edilmektedir. Diplomatik dilden uzaklaşan kendine has üslubu nedeniyle Trump dönemi vaka incelemesi, çevirmenlerin kamu diplomasisi alanındaki etkisini incelemek açısından da önemli veriler sunabilir.

İlk bölümde diplomatlarla çevirmenlerin üstlendikleri roller karşılaştırılacaktır. İkinci bölümde diplomatik çevirmenin iletişim filtresi olarak zaman kazandırma, moderatörlük ve eşik bekçisi rolleri ile uzlaştırma rolleri olan günah keçisi olma, kriz önleme ve arabuluculuk ele alınacaktır. Son bölümde çevirmenlerin Trump döneminde diplomasi dili, teamülleri ve aktörleri bağlamında oluşan boşluğu doldurmaya yönelik girişimlerine istinaden diplomaside artan önemi vurgulanacaktır.

\section{Diplomatik Çevirmen: Sadece Pasif bir Aktaran mı?}

Diplomasi, genel itibariyle, uluslararası ilişkilerin "kurnazlık ve zeka ile” yürütülerek sorunların silah kullanmadan ikna yoluyla çözülmesi olarak tanımlanmaktadır. ${ }^{31}$ Tarihsel kökeni Eski Mısır’a kadar uzanan diplomasi, yüzyıllar içinde gelişerek günümüzdeki halini almıştır. Roma İmparatorluğu döneminde diplomatik dokunulmazlık pratiği hayata geçirilirken, 15. ve 16. yüzyılda İtalyan şehir devletleri ilk defa daimi temsilcilik ve diplomatik arşivcilik uygulamalarına geçmiştir. ${ }^{32}$ Diplomasi, 17. yüzyıldan itibaren Fransa'daki Dışişleri Bakanlığı yetkilerinin artırılması ve diplomat eğitimine standart getirilmesiyle kurumsallaşmaya başlamıştır. ${ }^{33}$ Çok taraflı ve şeffaf diplomasi anlayışı Birinci Dünya Savaşı'ndan sonra ortaya çıkmıs ve özellikle İkinci Dünya Savaşı’ndan sonra BM'nin

28 Mona Baker, "Non-cognitive constraints and interpreter strategies in political interviews”, Karl Simms (der.), Translating sensitive Texts. Linguistic Aspects, Amsterdam, Rodopi,1997, s.113.

29 Kamu diplomasisi, kültür, eğitim vb yumuşak stratejilerle diğer ülke halklarının desteğini kazanmayı ve temsil edilen devletin uluslararası kamuoyundaki imajını yükseltmeyi hedeflemektedir. Bkz. Ellen Huijgh, "Public Diplomacy", Costas M. Constantinou, Pauline Kerr ve Paul Sharp (der.), The Sage Handbook of Diplomacy, Londra, Sage, 2016, s. 437-448.

30 Geoffrey R. Berridge, Diplomacy: Theory and Practice, 5. baskı, Hampshire, Palgrave Macmillan, 2010;

Bruce Gregory, "Public Diplomacy: Sunrise of an Academic Field", The ANNALS of the American Academy of Political and Social Science, Cilt 616, No 1, 2008, s. 274-290.

31 Ernest Satow, A Guide to Diplomatic Practice, Londra, Longmans, Green ve Co, 3. Baskı, 1932, s.1; Adam Watson, Diplomacy: The Dialogue between States, Londra, Taylor and Francis, 1982, s.2.

32 Harold Nicholson, The Evolution of Diplomatic Method, Londra: Constable, 1954, s.14-25.

33 Ibid, s. 50-55. 
kurulmasıyla dünya sathına yayılmıştır. ${ }^{34}$ Günümüzde diplomasi, diyalog ve müzakere yoluyla uluslararası aktörlerin ilişkilerini sürdürülebilir bir şekilde yürütmelerine olanak sağlayan "dünya siyasetinin belkemiği” olarak nitelendirilmektedir. ${ }^{35}$

Diplomatlar, diplomasinin ana aktörü olarak temsil ettikleri devletin yurtdışındaki yegâne temsilcisi, hatta "gözü, kulağı ve sesi" dir. ${ }^{36}$ Görevlerini yerine getirirken, öz benliklerinin dışına çıkar ve adeta devletin bir uzvu gibi hareket ederler. ${ }^{37}$ Der Derian'ın "yabancılaşma” (estrangement) olarak adlandırdığı bu durum, diplomatları devletin gerekli gördüğü her görevi sorgulamadan yapmaya yöneltir. ${ }^{38} \mathrm{Bu}$ yüzden, diplomatlar tarihte değişik kültürlerce yer yer düşman, rakip, pasif aktaran ya da medenileştirici olarak algılanmıştır. ${ }^{39}$

Diplomatların, temsil etme, bilgi toplama, iletişim kurma ve arabuluculuk olmak üzere dört temel görevi bulunmaktadır. Diplomatlar, resmi ve gayriresmî davetlere katılarak ve diğer devlet temsilcileriyle "yüz yüze" diyaloğa geçerek hem devletlerinin görünürlügünü artırırlar hem de edindikleri bilgileri devletlerine iletirler. ${ }^{40}$ Diplomatlar sadece bilgiye erişmekle kalmaz; aynı zamanda, doğru bilgiyi şüpheli bilgiden ayırt eden bir "filtre" işlevi görürler. ${ }^{41}$ Ayrıca devletler arası görüşmelerin gizli ve güvenli bir ortamda gerçekleşmesini sağlarlar ve taraflara zaman kazandırarak ilişkilere zarar verebilecek ani kararlar alınmasını önlerler. ${ }^{42}$ Dolayısıyla diplomatlar iki devlet arasındaki iletişimi daimi kılarak ortak işbirliği zemini hazırlarlar. ${ }^{43}$ Sharp’a göre, diplomatların gerçekleştirdiği temsil etme ve iletişim kurma işlevleri, uluslararası ilişkileri sağlıklı bir zemine oturtur ve sürdürülebilir kılar. ${ }^{44}$ Üstelik diplomatların gerektiğinde tek tarafı temsil etmenin ötesine geçerek arabuluculuk rolü üstlendikleri görülmüştür. ${ }^{45}$ İkna kabiliyeti gelişmiş görevliler olarak diplomatlar, hükümetleri ortak çıkarları olduğuna ikna ederek taraflar arasında karşılıklı güvenin tesis edilmesini ve orta yolun bulunmasını sağlarlar. ${ }^{46}$

1919 yılında imzalanan Versailles Antlaşması́nın ardından diplomasi dili Fransızca'nın tekelinden çımış ve diplomatik çevirmenlik uluslararası ilişkilerin olmazsa olmazı haline gelmiştir. ${ }^{47}$

34 Ibid, s. 90-93.

35 Ole J. Sending, Vincent Pouliot ve Iver B. Neumann "The Future of Diplomacy: Changing Practices, Evolving Relationships” International Journal, Cilt 66, No 3, 2011, s. 530.

36 Andrew F. Cooper, Jorge Heine, ve Ramesh Thakur, "Introduction: The Challenges of 21st-Century Diplomacy", Andrew F. Cooper, Jorge Heine, and Ramesh Thakur (der.), The Oxford Handbook of Modern Diplomacy, Oxford, Oxford University Press, 2013, s. 3.

37 Paul Sharp, Diplomatic Theory of International Relations, Cambridge: Cambridge University Press, 2009, s. 77.

38 James Der Derian, “Mediating estrangement: a theory for diplomacy”, Review of International Studies, Cilt 13, No 2, 1987, s. 107.

39 Sharp, "Diplomatic Theory of International Relations" s. 19, 42, 59.

40 Gülmez, "Do Diplomats matter in Foreign Policy?", s. 69; Marcus Holmes, “The Force of Face-to-Face Diplomacy: Mirror Neurons and the Problem of Intentions”, International Organization, Cilt 67, No 4, 2013, s. 833; Jönsson ve Hall, "Communication", s. 197.

41 Jeremy Black, A History of Diplomacy, Londra: Reaktion Books, s. 14.

42 Jönsson ve Hall, “Communication”, s. 196-197.

43 Berridge et al., "Diplomatic Theory”, s. 82

44 Sharp, "Diplomatic Theory of International Relations", s. 77.

45 Karin Aggestam, "Diplomatic mediation”, Costas M. Constantinou, Pauline Kerr ve Paul Sharp (der.), The SAGE Handbook of Diplomacy, Londra ve Kaliforniya, Sage, 2016, s. 223; Sharp, s.76.

46 Hedley Bull, The Anarchical Society; A Study of Order in World Politics, New York, Columbia University Press, 1977, s. 164

47 Tamas Baranyai, "The role of translation and interpretation in the diplomatic communication”, SKASE Journal of Translation and Interpretation, Cilt 5, No 2, 2011, s. 2-13. 
Daha önce de çevirmenler tarihin çeşitli dönemlerinde dış politika ve diplomasi alanlarında aktif görevler üstlenmiştir. ${ }^{48}$ Örneğin, 17. yüzyılda Fransız kaşif Samuel de Champlain’in oluşturduğu "mukim çevirmenler sistemi" içinde yer alan ve Avrupalı tüccarlarla yerli halk arasında çeviri yapan kişiler, hem rehber hem kaşif hem diplomat hem de tüccar olarak görülmekteydi. ${ }^{49}$

Osmanlı İmparatorluğu da Batı ile ilişkilerini sürdürürken 15. yüzyıldan itibaren dragoman yani tercüman kullanmış, 19. yüzyıldan itibaren de Osmanlı Devleti Tercüme Odası gibi kurumlar aracılığıyla kendi çevirmenlerini yetiştirmiştir. ${ }^{50} \mathrm{Bu}$ bağlamda, Divan-1 Hümayun Tercümanları ve Yabancı Elçilik ve Konsolosluk Tercümanları ön plana çıkmıştır. Divan-ı Hümayun tercümanlarının belge tercüme eden resmi görevliler olmanın çok ötesine geçtiği ve kendilerine tanınan yetkiler çerçevesinde Osmanlı diplomasisinin yürütülmesi ve Osmanlı dış politikasının şekillenmesinde rol oynadıkları bilinmektedir. ${ }^{51}$ Tercüman yetiştirme amacıyla kurulan "Dil Oğlanları Okulları" mezunları arasından seçilen ve genellikle gayrimüslim olan Yabancı Elçilik ve Konsolosluk Tercümanları da, Osmanlı devlet yönetimiyle ilgili bilgi sahibi oldukları ve önemli Osmanlı devlet yöneticileriyle şahsi ilişkiler kurabildikleri için yabancı Büyükelçiler için vazgeçilmez bir değer taşımışlardır. ${ }^{52}$

Çevirmenlerin 1815 Viyana Kongresi ile ön plana çıkan diplomatik sistemde diplomatların gerisinde kaldığı görülmüştür. ${ }^{53}$ Yine de bu durum çevirmenlerin diplomasi alanındaki etkinliklerini sonlandırmamıştır. Örneğin, 20. yüzyılın başlarında Japon dili uzmanı Britanyalı Ernest M. Satow çevirmenliği döneminde Japon devlet ve iş çevrelerinde önemli bağlantılar edinmiş, bu sayede iki ülke arasındaki görüşmelerde uzlaştırıcı rol oynamıştır. ${ }^{54}$ Sekiz yıllık başarılı diplomatik çevirmenlik tecrübesinden sonra Satow, kariyer diplomatlığına terfi etmiş ve uzun yıllar Büyükelçi ünvanıyla Britanya'yı Uzak doğu ülkelerinde temsil etmiştir. ${ }^{55}$ Yanısıra, Truman, Eisenhower ve Nixon gibi birçok ABD Başkanına çevirmenlik yapmış olan Vernon A.Walters, savunma politikaları ve gizli anlaşmalarda yapılması gereken düzenlemeler konusunda tavsiyelerde bulunmak gibi girişimleri dolayısıyla "perde arkası diplomatı" olarak ün yapmış ve Ronald Reagan döneminde Büyükelçi olarak atanmıştır. ${ }^{56}$

Uygulamaya bakıldığında, çevirmenler tarafların birbirini doğru anlaması için kolaylaştırıcı bir zemin hazırlayarak diplomatların görevlerini tamamlayıcı etkide bulunurlar. Günümüzde diplomatik çevirmenler, Bakanlıklar ve Meclisler gibi ulusal kurumların yanısıra BM, Avrupa Birliği ve Kuzey Atlantik Antlaşması Örgütü gibi uluslararası kuruluşlarda görev alır. ${ }^{57}$ Çevirmenlerin çevirdikleri metne dolaylı ve doğrudan müdahalelerde bulunduğu ve her zaman tarafsız kalamadıkları

48 Jean Delisle ve Judith Woodsworth (der.), Translation through History, Philadelphia, ABD, John Benjamins, 1995 , s. 247.

49 Ibid, s. 259

50 Elvin Abbasbeyli, “The role of dragomans in the Ottoman Empire”, AIIC, 2015, https://aiic.net/page/7219 (Erişim Tarihi 5 Eylül 2019)

51 Bilgin Aydın, Divan-ı Hümayun Tercümanları ve Osmanlı Kültür ve Diplomasisindeki Yerleri: Osmanlı Araştırmaları XXIX, İstanbul, Enderun, 2008, s. 42.

52 Sakine Eruz, Çokkültürlülük ve çevirmenler: Osmanlı Devleti’nde çeviri etkinliği ve çevirmenler, İstanbul, Multilingual, 2010, s. 67.

53 Hakeme bu hususu hatırlattığı için teşekkür ederiz.

54 Harris, “Ernest Satow's Early Career as Diplomatic Interpreter”, s. 126-127.

55 Ibid, s. 124-125.

56 Roland, “Interpreters as Diplomats”, s. 267.

57 Maria Rosaria Buri, "Interpreting in diplomatic settings", aiic.net, 29 Ekim 2015, http://aiic.net/p/7349 (Erişim Tarihi 5 Mayis 2019). 
görülmüştür. ${ }^{58}$ Örneğin, Sovyet Dışişleri Bakanı Vyaçeslav Molotov, 1947 yılında Paris'te düzenlenen Marshall yardımlarıyla ilgili Fransa, İngiltere ve SSCB Dışişleri Bakanlarının katıldığı konferans sırasında konuşmasının çevirisinin ardından çevirmen André Kaminker’e dönerek "Ben tam olarak bunu demedim” diyerek çeviriye itiraz etmiş, Kaminker de Molotov’a "Hayır, demediniz ama demeniz gerekirdi" şeklinde cevap vermiştir. ${ }^{59}$

Japonya'nın önde gelen diplomatik çevirmenlerinden Masao Kunihiro da çevirmenin "robot" ya da "makine" olmadığını, mesajları çevirirken adeta bir "filtre" işlevi gördüğünü açıklamıştır. ${ }^{60}$ Yani, çevirmenlerin diplomatik görüşmeleri veya karar anını olumlu veya olumsuz anlamda etkilemesi kaçınılmazdır. ${ }^{61}$ Özellikle yan anlamları olan ifadelerin çevirisi sırasında çevirmenler gerginliği azaltma ve uzlaşı zemini hazırlama açısından etkili olabilir. Dolayısıyla, çevirmen sadece pasif bir vekil değil, uluslararası ilişkilere olumlu veya olumsuz etkileri olan bir aktör olarak düşünülebilir.

"Asil-vekil" (principal-agent) tartışmasına göre çevirmenler de diplomatlar da vekildir. Yani yetkileri karar vericiler tarafından sınırlandırılmıştır. Örneğin, çevirmenlerin konuşma metnine kelimesi kelimesine sadık kaldığı varsayılır. Dolayısıyla, literatürde çevirmenlerin liderler arası görüşmeler sırasında yaptıkları dolaylı ve doğrudan etkiler önemsenmez. ${ }^{62}$ Çevirmenler görüşmede çıabilecek sorunlara doğrudan müdahil olan bir "aktör” olarak görülmez. Bu görünmezlik algısı, sosyolog Goffman'ın bir tiyatro sahnesinde arka planda yer alan ama oyunun parçası olmayan kişiyi anlatmak için kullandığ1 "var olmayan” veya "önemsiz kişi” anlamına gelen "non-person” terimiyle açıklanabilir. ${ }^{63}$ Uluslararası basın, görüşmeler sırasında çekilen fotoğrafların altında katılımcıların isimlerini belirtirken fotoğrafta bulunan çevirmenin adını yazmak yerine "bir kişi atla" (skip one person) ifadesini kullanır. ${ }^{64}$ Dolayısıyla, ciddi bir hata yapmadıkça çevirmen "görünmez bir filtre" gibidir. $^{65}$

Özellikle diplomasi teamüllerini dışlayıcı bir üslup benimseyen siyasi liderlerin çevirisini yapma sorumluluğu, çevirmenlere daha aktif müdahalelerde bulunma ve geleneksel diplomasi aktörlerinin devre dışı kalmasından doğan boşluğu giderme firsatı sunmaktadır. Bu bağlamda, 1815 öncesi dönemi anımsatan şekilde çevirmenlerin diplomasi sahnesine aktör olarak dönüp dönmediği sorusu gündeme gelebilir. ${ }^{66}$ İzleyen bölümde, çevirmenlerin "iletişim filtresi” ve "uzlaştırıcı" rollerinin diplomatların asli görevleriyle örtüştüğü görülmektedir.

58 Esra Özkaya, “Konferans Çevirmenliğinde Normlar Işı̆̆ında Tarafsızlık Kavramı”, Yayınlanmamış doktora tezi, İstanbul Üniversitesi, 2015.

59 Ruth Ailene Roland, Interpreters as Diplomats: A Diplomatic History of the Role of Interpreters in World Politics, Ottawa, University of Ottawa Press, 1999, s. 167.

60 Kumiko Torikai, Voices of the invisible presence: Diplomatic interpreters in post-world war II Japan, NLD, John Benjamins, 2009, s. 143

61 Bulut, “Tercüme Hatası!?”.

62 Wadensjö, s. 67

63 Erving Goffman, The presentation of self in everyday life, New York, Doubleday, 1959.

64 Torikai, "Voices of the invisible presence".

65 Christina Schäffner, "Strategies of translating political texts", Anna Trosborg (der.) Text Typology and Translation, Amsterdam/Philadephia, John Benjamins, 1997, s. 119-143.

66 Hakeme önerisi için teşekkür ederiz. 


\section{IIetişim Filtresi Olarak Çevirmenler}

Diplomatik çevirmenler, iki taraf arasında meydana gelebilecek yanlış anlaşılmaları önleyerek uluslararası görüşmelerin diplomatik teamüller çerçevesinde yapıcı bir atmosferde gerçekleşmesini sağlarlar. Kültürel ve dilsel farklılıklar gözetilmeden yapılan hatalı veya eksik bir çeviri, dış politika yapanları yanlış yönlendirebilir ve uluslararası ilişkilerin bozulmasına yol açabilir. Örneğin, Nixon döneminde Japonya İmparatoru Hirohito ile yapılan müzakereler sırasında Hirohito kendisine yöneltilen bir soruyu "Bir düşüneyim” şeklinde yanıtlamıştır. Çevirmenin Japon kültüründe bu yanıtın "Hayır" anlamına geldiğini belirtmemesi, ABD-Japonya ilişkilerini sarsan bir yanlış anlamaya ve güven bunalımına sebep olmuştur. ${ }^{67}$

Ayrıca, çevirmenin kullandığı bir sözcük veya vurgu da yanlış anlamalara ve uluslararası krize yol açabilir. Potsdam Konferansı'nın ertesinde ABD, Rusya, İngiltere ve Çin Devlet Başkanlarının Japonya'ya yönelik “Teslim ol!” ültimatomunun ardından Japonya Başbakanı Suzuki'nin düzenlediği basın toplantısında "mokusatsu" ifadesini kullanması sözcügün çok anlamlı doğası nedeniyle karışıklığa yol açmıştır. Çevirmenlerin "mokusatsu” sözcügünün diğer anlamlarını göz ardı ederek sözcüğü ültimatoma istinaden “aşağılanarak reddedildi” şeklinde çevirmesi, ABD Başkanı Truman’ın Hiroşima ve Nagazaki’ye nükleer saldırı kararı almasında etkili olmuştur. ${ }^{68}$ Japonya Başbakanının aslında ültimatomu reddetmediği, aksine "sükûnet içinde değerlendireceğini" söylediği iddia edilmiştir. ${ }^{69} \mathrm{Bu}$ örnek, hatalı çevirinin uluslararası ilişkilerde ne kadar yıkıcı sonuçlara yol açtığını göstermektedir.

1956 yılında Khruschev'in Moskova'da Batılı temsilcilerle yaptığ ettiği sözlerin çevirmen tarafından Batılı temsilcilere "Sizi gömeceğiz" (We will bury you) şeklinde çevrilmesi de ABD-SSCB ilişkilerinde büyük gerginliğe yol açmıştır. ${ }^{70} \mathrm{ABD}$ temsilcisi BM görüşmeleri sırasında bu ifadeye atıfta bulunarak Sovyetlerin saldırgan tutumunun barış içinde bir arada yaşama ilkesine engel oluşturduğunu iddia etmiştir. ${ }^{71}$ Kruschev ise sözlerinin yanlış çevrildiğini, "gömmek" kelimesini tehdit amaçlı kullanmadığını açıklamış ve o sözleri sarf ederken komünist ideolojinin kapitalist sistem sona erdikten sonra da devam edeceğine dair tarihsel bir öngörüden bahsettiğini söylemiştir. ${ }^{72}$

Gürcistan, Ukrayna ve Suriye'de meydana gelen çatışmaların ardından iyice gerilen ABDRusya ilişkilerine "sıfırdan başlamayı" (reset) öngören Obama yönetiminin politikası da çeviri hatasına kurban gitmiştir. ABD Dışişleri Bakanı Hillary Clinton 2009 yılında Cenevre'de düzenlenen basına açık görüşmede Rus meslektaşı Sergey Lavrov’a sembolik olarak ABD-Rusya ilişkilerini barışçı düzlemde "yeniden başlatma tuşu” hediye edince Lavrov, tuşun üzerinde yazan Rusça ifadenin "reset" (perezagruzka) değil, “overcharged” (peregruzka) yani “kazıklanma” olduğunu belirtmiştir. ${ }^{73}$ Clinton’un

67 Ibid.

68 Kazuo Kawai, “Mokusatsu, Japan's Response to the Potsdam Declaration”, Pacific Historical Review, Cilt 19, No 4, 1950, s. $409-414$.

69 Ibid.

70 “We Will Bury You!”, TIME, 26 Kasım 1956.

71 CIA- Central Intelligence Agency, “Kruschev’s 'We Will Bury You!' raporu”, 7 Şubat 1962, https://www.cia.gov/ library/readingroom/docs/CIA-RDP73B00296R000200040087-1.pdf (Erişim Tarihi 5 Eylül 2019).

72 Ibid.

73 “Clinton gift of 'reset' button lost in translation”, Associated Press Arşiv, 6 Mart 2009, http://www.aparchive.com/ metadata/youtube/30bbfb5200b0b5a83c4bb3a0f5eaa8f8 (Erişim Tarihi 5 Eylül 2019). 
yanıtı şakayla karışık "Bizi kazıklamanıza müsaade etmeyiz" olunca, uluslararası kamuoyunda ABDRusya arasındaki güven bunalımının devam edeceği izlenimi doğmuştur. ${ }^{74}$

Çevirmenlerin iletişim filtresi rolünün ne kadar önemli olduğu, özellikle bu rolü oynamakta başarısız olduklarında ortaya çıkmaktadır. Siyaseten hassas alanlarda çalışan diplomatik çevirmenlerin her dediğine dikkat etmesi gerekir çünkü diplomatik iletişimde doğru olanı, doğru zamanda ve doğru üslupla söylemek en az doğruyu söylemek kadar önem taşır. ${ }^{75}$ Bunun için diplomatik çevirmenlerin diplomatlara özgü bir üslup benimsemesi ve nezaketsizlik ya da tahrikten kaçınması gerekir. Çevirmenlerin "iletişim filtresi” rolü incelendiğinde görüşmelere ne derece müdahil olduğuna bağlı olarak pasiften aktife doğru görüşmecilere zaman kazandırma, moderatörlük ve eşik bekçisi işlevleri öne çıkar.

Zaman kazandırma: Çevirmensiz bir görüşmede hemen tepki ve yanıt verilmesi beklenirken çeviri yapılan bir görüşmede taraflar verecekleri tepkiyi düşünmek için zaman kazanır. 25 Ekim 1962 tarihli BM Güvenlik Konseyi oturumunda ABD'li temsilci Adlai Stevenson'nn Sovyet temsilci Valerian Zorin'e SSCB’nin Küba'ya balistik füze yerleştirip yerleştirmediğini sorduktan sonra "Çeviriyi beklemeden evet veya hayır diye yanıtlayın” diye baskı yapması, çevirmenin görüşmecilere zaman kazandırma işlevini vurgulamıştır. Hatta bu işlevin bazen görüşmecilerden sadece birinin lehine kullanılabileceği endişesini ortaya çıkarmıştır. ABD Başkanı George W. Bush'un 2007 yılında Almanya'da gerçekleşen G8 zirvesi sırasında konuşmasının Almanca'ya çevirisini "Nasıl olsa herkes İngilizce konuşuyor, değil mi?"”6 diyerek durdurarak konuşmaya devam etmek istemesi de bu bağlamda değerlendirilebilir.

Moderatörlük: Uluslararası görüşmelerde görev alan sözlü çevirmenler moderatörlük de yapmaktadır. ${ }^{77} \mathrm{Bu}$ bağlamda çevirmen söz sırasının tayini, konuşturma/susturma, diyalog aralıklarını belirleme ve soru-cevap düzenini ayarlama yetkisini kullanır. ${ }^{78}$ Moderatörlük, liderle çevirmen arasındaki asimetrik güç ilişkisini devre dışı bırakır ve çevirmenin uluslararası görüşmelere bazı müdahalelerde bulunmasına imkân tanır. Örneğin, Moskova'daki Dışişleri Bakanları toplantısı sırasında Rus çevirmen Oleg Troyanovski, İngiltere temsilcisi Ernest Bevin'i SSCB lideri Stalin hakkında esprili ifadeler kullandığı için eleştirmiştir. ${ }^{79}$ Çevirmenin daha aktif rol alarak taraflar arası görüşmelerde yanlış anlaşılmaları bertaraf etmek için bazen görüşmeye doğrudan müdahil olduğu da görülmüştür. ${ }^{80}$ Örneğin, lider kültürel göndermeler yaptığında çevirmen açıklayıcı ifadeler ve sorular ekleyebilmektedir. ${ }^{81}$ Yedi ABD Başkanına çevirmenlik yapan Harry Obst, bazen görüşmeler sırasında “Sayın Başkanım, bunu mu demek istediniz?” diyerek lidere kibarca ifadeyi yeniden değerlendirme ve değiştirme imkânı verdiğini belirtmiştir. ${ }^{82}$

\section{Ibid.}

75 Kamel S. Abu Jaber, "Language and Diplomacy", Jovan Kurbalija and Hannah Slavik (der.), Language and Diplomacy, Malta, Diploprojects, 2001, s. 50-51.

76 Linda Jaivin, “Found in translation: In praise of a plural world”, Quarterly Essay, Cilt 52, No 1, 2013, s.1.

77 Per Linell, "Interpreting as communication”, Yves Gambier, Daniel Gile and Christopher Taylor (der.), Conference Interpreting: Current Trends in Research, Amsterdam/Philadelphia, John Benjamins, 1997, s. 53-69.

78 Bistra Alexieva, “A Typology of Interpreter-Mediated Events”, The Translator, Cilt 3, No 2, 1997, s 171.

79 Roland, “Interpreters as Diplomats", s. 167

80 Şeyda Eraslan-Gerçek, "Sözlü çeviride makro ve mikro bağlamlar”, G. Sert (der.) Çeviri, Araştırma, İnceleme, Eleştiri, İzmir, Dokuz Eylül Üniversitesi Matbaası, 2009, s. 94-120.

81 Ibid.

82 David A. Graham, “The Strange, High-Pressure Work of Presidential Interpreters”, The Atlantic, 7 Temmuz 2017, https:// www.theatlantic.com/international/archive/2017/07/trump-interpreters/532968/ (Erişim Tarihi 5 Eylül 2019). 
Eşik bekçisi (gatekeeper): Diplomatik alanda sözlü çeviri yapan kişi “dil cambazı” (linguistic acrobats) olarak düşünülebilir. ${ }^{83}$ Argo ve kaba ifadeleri olduğu gibi çevirmek yerine diplomasi dilinde daha makul karşılanan ifadeleri bulup kullanmak ve çevrilecek metni kabul gören etikete ve normlara uygun hale getirmek diplomatik çevirmenlikte başvurulan yaygın uygulamalardır. ${ }^{84}$ Örneğin, ilk kez simültane çeviri kullanılan 1987 yılında Washington'da düzenlenen ABD-SSCB görüşmesinde Ronald Reagan’ın SSCB için İngilizce “adversary” sözcüğünü kullanması, görüşmede bulunan çevirmenleri zor durumda bırakmıştı. ABD Başkanı’nın çevirmeni Dimitry Zarechnak sözcügü Rusçaya ilk anlamıyla yani düşmanca rekabet ve hasım anlamına gelen "protivniki" (foe) olarak değil de, daha yumuşak bir ifade olan ve rakip anlamına gelen "soperniki" (competitor) olarak Rus muhataplarına çevirmiştir. ${ }^{85}$ 2001 yılında verdiği bir röportajda Zarechnak sözcüğu Rusça’ya çevirirken "protivniki” kelimesini kullanmamasının asıl sebebinin iğrenç anlamına gelen "protivniy" kelimesine çok benzemesi olduğunu açıklamıştır. ${ }^{86}$ Sovyet resmi belgelerinde "adversary" kelimesi çoğunlukla "competitor" olarak çevrilerek kelimenin anlamı yumuşatılmıştır. Rus liderle görüşmesinin hemen öncesinde Trump’ın Avrupa Birliği için “foe” sözcüğünü kullanmaktan sakınmazken, Rusya için "competitor” sözcügünü tercih etmesi ${ }^{87}$ bu bağlamda dikkat çekicidir.

Çevirmenler diplomatik dilin korunmasına yönelik seçimler yapmaktadır. Soğuk Savaş sonrası düzende İran, Irak, Küba ve Kuzey Kore gibi liberal demokrasiye uyumlu davranmayan ülkeleri itham etmek için kullanılan "haydut devletler" (rogue nations) tabiri, diplomatik dile uygun bulunmayarak ABD Dışişleri Bakanlığı çevirmenleri tarafından "endişe verici devletler" (states of concern) şeklinde çevrilmiştir. ${ }^{88}$ Ayrıca, 2015 yılında düzenlenen G20 Liderler Zirvesi basın konferansında, CNN muhabirlerinden Jim Acosta’nın ABD Başkanı Obama’ya IŞİD’i kastederek yönelttiği "Neden bu soysuzları ortadan kaldıramıoruz?" (Why can't we take out these bastards?) sorusu simültane çevirmen tarafından Türkçe'ye "Neden bu kötü adamları yenemiyoruz?" şeklinde çevrilmiştir. ${ }^{89}$ Bu bağlamda, çevirmenin diplomatik dili muhafaza eden bir "eşik bekçisi” olduğu görülmektedir. ${ }^{90}$

Eşik bekçisi, neyin çevrilip neyin çevrilmeyeceği kararını veren aktördür. Eşik bekçisi rolündeki çevirmen seçici davranır ve standart dışı gördüğü ifadeleri çeviri dışı bırakır. ${ }^{91}$ Tarihi bir örnek, Rus çevirmen Troyanovsky'nin Khruschev'in Tanrı'ya yaptığı göndermeleri komünist bir lidere yakışmayacağını düşünerek çevirmemesidir. ${ }^{92}$ Troyanovsky, Khruschev'in Ukrayna sınırındaki köyüne ve işçi geçmişine ait standart dışı ifadelerini de o dönemde kabul gören resmi söylemlere

83 Delisle ve Woodsworth, "Translation through History".

84 Belkıs Çorakçı-Dişbudak, Tane Tane Simültane, İstanbul, Altın Kitapevi, 1991.

85 Igor Korchilov,Translating History: 30 Years on the Front Lines of Diplomacy with a Top Russian Interpreter, New York, Simon and Schuster, 1999, s. 65.

86 “Interpreting Bigwigs", NPR, 21 Temmuz 2001, https://www.npr.org/templates/story/story.php?storyId=1126234 (Erişim Tarihi 5 Eylül 2019).

87 "I think the European Union is a foe, Trump says ahead of Putin meeting in Helsinki", CBS NEWS, 15 Temmuz 2018; Alissa de Carbonnel, “Trump says Putin 'competitor', not enemy”, REUTERS, 12 Temmuz 2018.

88 “Updating Diplomacy's Language”, The New York Times, 23 Haziran 2000.

89 “Tercüman, muhabirin argo konuşmasını bakın nasıl çevirdi?”, Milliyet, 17 Kasım 2015.

90 Linell, "Interpreting as communication".

91 Nihal Yetkin-Karakoç, "Diplomasi Çevirmeni için Taraflılık/Tarafsızlık ve Sözlü Diplomasi Çevirisindeki Denetim/ Müdahalelere Bir Bakış”, Çeviribilim ve Uygulamaları Dergisi, Cilt 24, No 1, 2018, s. 93.

92 Roland, "Interpreters as Diplomats", s.167 
uygun olarak "düzeltmiştir". ${ }^{93}$ Eşik bekçiliği, çevirmenin zaman kazandırma ve arabuluculuk rollerine kıyasla daha aktif ve doğrudan metne müdahale ettiği bir roldür.

Çevirmenler sadece liderler arasındaki görüşmelerde değil, liderle halk arasında da iletişim filtresi işlevi görür. Çevirmenler, liderlerin söylemlerini toplumsal ve diplomatik normlara uygun hale getirerek hedef kamuoyunun daha kolay anlayıp karşılık verebileceği bir söylem haline getirirler. Dolayısıyla, çevirmenler liderlerin ve ülkelerin uluslararası imajına doğrudan olumlu veya olumsuz etkide bulunabilirler. ${ }^{94}$ Örneğin, 2003 yılındaki Irak işgaline karşı eleştirel bir tutum sergileyen Fransız lider Jacques Chirac işgale destek veren Amerikalılar ve Avrupalıların "sessiz kalmak için önemli bir firsatı kaçırdıklarını" (ils ont manqué une bonne occasion de se taire) söylemiştir. ${ }^{95} \mathrm{ABD}$ basınında Chirac'in sözleri "seslerini kesmek için önemli bir firsatı kaçırdılar" (they missed a good occasion to shut up) şeklinde çevrilince Fransız lider ABD kamuoyunda müttefik bir ülkenin lideri olarak değil de, kaba bir düşman gibi algılanmıştır. Bu bağlamda, çevirmenlerin yurtdışındaki halkların desteğini kazanma amacıyla oluşturulan kamu diplomasisi alanında da etkili olduğu göz önünde bulundurulmalıdır. İzleyen kısımda çevirmenin diplomaside başlı başına bir aktör olarak öne çıktığı "uzlaştırma" rolleri incelenecektir.

\section{Uzlaştırma}

Uzlaştırma, çevirmenin "iletişim filtresi” rolünün ötesine geçerek sorunların çözümüne, anlaşma zemini sağlanmasına ve ortak çıkar üretilmesine aktif olarak katkıda bulunduğuna işaret eder. $\mathrm{Bu}$ açıdan, çevirmenin başlı başına bir aktör olarak liderler arası diplomatik görüşmelere müdahil olduğu düşünülebilir. Çevirmenin uzlaştırma rolleri pasiften daha aktif role doğru sırasıyla günah keçisi olma, kriz önleme ve arabuluculuktur.

Günah keçisi: Çevirmenler de tıpkı diplomatlar gibi hayranlık-düşmanlık, saygınlıkküçümsenme gibi ikilemlerin hedefi olmuştur. ${ }^{96}$ Diplomatlar da çevirmenler de liderlerin uzantıları olarak görülmekte, başıı başına bir aktör olarak değerlendirilmemektedir. Kendilerine duyulan güven ve verilen yetki sınırlı olduğu için liderlerle aralarında hiyerarşik ve asimetrik bir güç ilişkisi olduğu vurgulanır. ${ }^{97} \mathrm{Bu}$ nedenle, dış politika alanındaki başarılı girişimlerde diplomat da çevirmen de liderler tarafından etkili aktörler olarak anılmaz. Ancak başarısızlıklarda günah keçisi olarak seçilebilirler. ${ }^{98} \mathrm{Bu}$ durum, aslında çevirmenlere önemli bir uzlaştırma işlevi kazandırır çünkü çevirmenler gerektiğinde günah keçisi rolünü oynayarak liderler arasında bir emniyet supabı görevi üstlenirler. Taraflar arasında oluşan bir gerginlik anında, yanlış anlamanın -haklı veya haksız şekilde- bir çeviri hatasından ileri geldiği iddia edilerek ortam yumuşatılır ve taraflar rencide edilmeden görüşmelerin devamı sağlanır. ${ }^{99}$

93 Manuela Fernández Sánchez, "Understanding interpreting and diplomacy: Reflections on the early Cold War”, Michael Kelly, Hilary Footitt, Myriam Salama-Carr (der.), The Palgrave Handbook of Languages and conflict, İsviçre, Palgrave MacMillan, 2019, s.395-419.

94 Vicki Ann Cremona and Helena Mallia, “Interpretation and Diplomacy”, Jovan Kurbalija and Hannah Slavik (der.), Language and Diplomacy, Malta, Diploprojects, 2001, s. 301. https://www.diplomacy.edu/sites/default/files/ Language_Diplomacy_Chapter19.PDF.(Erişim Tarihi 5 Eylül 2019).

95 Eleanor Levieux ve Michel Levieux, “The World; No, Chirac Didn’t Say 'Shut Up”, The New York Times, 23 Şubat 2003.

96 Michael Cronin, “The empire talks back: Orality, heteronymy and the cultural turn”, Franz Pöchhacker ve Miriam Schlesinger (der.), The Interpreting Studies Reader, Londra ve New York, Routledge, 2002, s. 392.

97 Daniel Gile, Basic concepts and models for interpreter and translator training, Amsterdam/Philadelphia, John Benjamins, 2009.

98 Morry Sofer, The Global Translator's Handbook, UK, Schreiber, 2013.

99 Cremona ve Mallia, "Interpretation and Diplomacy", s. 304. 
Örneğin, 1999'da IMF toplantısı sırasında sözlü çevirmenin "konsolidasyon” sözcügünü olduğu gibi çevirmesinin ardından, konuyla ilgili eleştiri okları sözcüğü kullanan temsilci yerine çevirmene yönetilmiş ve temsilciler arasındaki görüşmelerin devam etmesi sağlanmıştır. ${ }^{100}$

Kriz önleyici: Siyasilere uluslararası görüşmelerinde danışmanlık yapabilecek seviyede konuya hakim olan çevirmenler ya da diğer bir deyişle "danışman-çevirmenler" de liderlerin söylemlerini oluşturma ve yeniden düzenleme konusunda geniş inisiyatif almaktadır. ${ }^{101}$ Kriz önleyici uzlaştırma rolünde çevirmen, eşik bekçiliğinin ötesine geçer ve tarafların ulusal düzeydeki siyasi, kültürel ve diğer hassasiyetlerini göz önünde bulundurarak doğrudan çatışma yaratma potansiyeli olan ifadelerin çevirisi sırasında metne müdahalelerde bulunur. Örneğin, 16. yüzyılda Osmanlı Sultanı III. Murat ve İngiltere Kraliçesi I. Elizabeth arasındaki diplomatik yazışmaların Latince'ye çevirisinde Sultan'ın Kraliçe’yi eşit statüde görmediğini belirten ifadeler yerine iki ülke arasındaki dostluğu vurgulayan ifadeler kullanılarak olası bir kriz önlenmiştir. ${ }^{102}$

Arabulucu: Liderler ve diplomatlar genellikle yüksek iletişim becerisine sahip olan ve yaratacakları etkiyi ve kanaati iyi ayarlayabilen iletişim uzmanlarıdır. Çevirmenlerin de üst düzey yetkililerin kullandığı söylemlerin çevirisini yaparken aynı öncelikleri gözetmesi beklenir. ${ }^{103}$ Diplomatik çevirmenler aktaranla aktarılan arasında köprü işlevi gören bir ara kültürü oluşturur. ${ }^{104} \mathrm{Bu}$ bağlamda çevirmenler literatürde "kültürlerarası iletişim uzmanı"105, "kültür simsarı" (cultural broker) ${ }^{106}$, "kültürel arabulucu” (cultural mediator $)^{107}$ ve "kültürel büyükelçi” ${ }^{108}$ olarak adlandırılmıştır. ${ }^{109}$

Diplomatlar gibi çevirmenler de, uygun koşullar oluştuğunda tarafsız ve hakkaniyetli bir aktör olarak görülmeyi başarıp her iki tarafın da güvenini kazanabilir ve arabuluculuk rolünü etkin bir şekilde uygulayabilir. Nixon ve ulusal güvenlik danışmanı Kissinger ABD Dışişleri Bakanlığı personeline siyasi açıdan mesafeli yaklaştıkları için yabancı temsilcilerle görüşmelerinde sadece çok güvendikleri ve $A B D$ Dışişleri Bakanına bile bilgi sızdırmayacak çevirmenlerle çalışmayı tercih ediyorlardı. Örneğin, Soğuk Savaş dönemi ABD-SSCB görüşmelerinde önemli rol oynayan Rus çevirmen Viktor Sukhodrev hem SSCB’nin hem de ABD’nin güvenini kazanmıştı. Sukhodrev, 1972 yılındaki NixonBrezhnev görüşmesine tek çevirmen olarak katılmıştır. Nixon hatıratında Sukhodrev'in hem Rusça hem İngilizce'yi çok iyi konuşan "mükemmel bir dilbilimci” olduğunu bildiği için ve Brezhnev'in bu şekilde daha özgür bir şekilde konuşacağına inandığı için kendi çevirmeni olmadan görüşmeye

100 Alev K. Bulut, "Davos ve Çeviri: Hep Aynı Hikaye”, Çeviribilim, 2009, s. 79-80, http://ceviribilim.com/?p=1477 (Erişim Tarihi 5 Eylül 2019).

101 Turgay Kurultay, “Davos'ta çevirinin serencamı”, Ç. N. Çeviri Edebiyatı, Sayı 9, 2009, s. 124-132.

102 Bernard Lewis, What Went Wrong? Western Impact and Middle Eastern Response, Oxford, Oxford University Press, 2001, s. 24-25.

103 Bulut, "Tercüme Hatası".

104 Michael Cronin, Across the lines: Travel, Language and Translation, Cork: Cork University Press, 2000, s. 150.

105 Hans J. Vermeer, Skopos and Commission in Translational Action. Reading in Translation Theory, Helsinki, Oy Finn Lectura Ob, 1989, s. 173-187.

106 Nancy Hagedorn, "A Friend to go between them: The Interpreter as Cultural Broker During Anglo-Iroquois Councils, 1740-70", Ethnohistory 1954-1999, Cilt 35, No 1, 1988, s. 60-80.

107 Kristina Gustafsson, Eva Norström, Ingrid Fioretos, “The interpreter: a cultural broker?”, Christina Schäffner, Krzysztof Kredens, Yvonne Fowler (der.), Interpreting in a changing landscape: Selected papers from Critical Link 6, Amsterdam, John Benjamins, 2013, s. 187-202.

108 Charlotte Baker-Shenk, “The Interpreter: Machine, advocate or ally?”, J. Plant Moeller (der.), Expanding Horizons, Silver Spring, MD, RID publications, 1991, s.120-140.

109 Fernández Sánchez, “Understanding interpreting and diplomacy”, s. 419. 
girdiğini açıklamıştır. ${ }^{110}$ Dolayısıyla, Sukhodrev, yalnızca Sovyet liderlerin İngilizce'deki sesi değil, aynı zamanda Amerikalı liderlerin Rus dilindeki sesi haline gelerek çevirmenlik mesleğinde çığır açan bir kariyere imza atmıştı. ${ }^{111} 2014$ yılında vefat ettiğinde Rus Dışişleri Bakanlığı Sukhodrev’i ABD-SSCB ilişkilerindeki en önemli olayların "doğrudan katılımcısı" ( direct participant) olarak nitelemiştir. ${ }^{112}$

ABD Dışişleri Bakanı Condoleezza Rice da hatıratında, ABD Başkanlarının Arapça çevirisini yapan Gamal Helal'in hem ABD hem de Suudi Arabistan temsilcilerinin güvenini kazandığını vurgulamıştır. Gamal Helal, Suudi Arabistan Prensi Abdullah'ın 2002 yılında George W. Bush'un çiftlik evini ziyareti sırasında kendi heyetiyle yaptığı gizli görüşmeye katılabilmiş ve görüşmede heyetin Batı Şeria'daki İsrail saldırılarına tepki olarak ABD ziyaretini erken sonlandırma kararını Busha önceden bildirerek iki taraf arasında yeniden anlaşma sağlanmasına katkıda bulunmuştur. ${ }^{113}$

Dolayısıyla, çevirmenler pasif bir vekil olmanın ötesindedir. Özellikle iletişimi kolaylaştırma, diplomasi dili ile teamüllerini koruma ve uzlaştırma rolleri sayesinde çevirmenler, diplomatların görevlerini pekiştirici rol oynamaktadır. Üstelik çevirmenler diplomatların liderler tarafından geri plana itildiği dönemlerde ortaya çıkan diplomatik otorite boşluğunu gidermek için avantajlı bir konumda bulunmaktadır. Diplomatların hareket alanı kısıtlanırken çevirmenlerin etki alanı genişlemekte, bu da çevirmenleri diplomatik arenada daha çok inisiyatif almaya yöneltebilmektedir. İzleyen bölümde Trump döneminde çevirmenlerin diplomasi alanında artan etkinliği -özellikle iletişim filtresi ve uzlaştırma bağlamındaki rolleri-incelenecektir.

\section{Trump Döneminde Diplomasi Karşıtlığı ve Sırdaş Çevirmenler}

Kendine has üslubu ve diline ek olarak, Trump’ın ABD devlet erkânına karşı duyduğu güvensizlik ve kararlarını doğrudan sosyal medya yoluyla iletme eğilimi, geleneksel diplomatik prosedürleri ve aktörleri önemli süreçlerin dışında bırakmaktadır. Örneğin, Trump'ın Putin'le baş başa görüşmesinin hemen öncesinde gündem konuları sorulduğunda Trump'ın ulusal güvenlik danışmanı basına "Başkan ne isterse onu konuşur" diye yanıt vererek geleneksel hazırlıkların yapılmadığını ve önceden belirlenmiş "spesifik bir görüşme gündemi olmadığını" itiraf etmiştir. ${ }^{114} 2017$ yılında Hamburg'da düzenlenen G20 zirvesi sırasında Trump, Putin’le Dışişleri Bakanlarının ve çevirmenlerin katıldığı ilk resmi görüşmesinin ardından çevirmeninin notlarını alarak kimseye bilgi vermemesini tembihlemiştir. ${ }^{115}$ Akşam yemeği sırasında da Putin'le sadece Rus çevirmenin bulunduğu bir görüşme gerçekleştirmiştir. ${ }^{116}$ Trump'ın bu tür standart dışı tutumları ABD’li siyasi ve diplomatik çevrelerin tepkisini çekmiştir.

Trump yönetiminde görev alan önemli aktörlerin bazen çevirmen olmadan görüşmelere girdikleri ancak bu görüşmelerin $\mathrm{ABD}$ lehine sonuçlanmadığı görülmektedir. Örneğin, ABD Dışişleri Bakanı Rex Tillerson'un Şubat 2018'de Ankara'da Türkiye Cumhurbaşkanı ile görüşmesi sırasında yanında Amerikalı bir çevirmenin olmaması Amerikan kamuoyunda skandal olarak

110 "Viktor Sukhodrev, interpreter at key Soviet-US summits, dies at 81", The Guardian, 16 Mayıs 2014.

111 Andrew Roth, “Viktor M. Sukhodrev, Soviet Leaders' Trusted Interpreter, Dies at 81”, The New York Times, 19 Mayis 2014. 112 Ibid.

113 Condoleezza Rice, No Higher Honour: A Memoir of My Years in Washington, New York, Simon and Schuster, 2011. 114 Roberta Rampton, "Pressure builds on Trump at home over pledge for closer Moscow ties", REUTERS, 4 Temmuz 2017. 115 Peter Baker, “Trump and Putin have met five times: What was said is a mystery”, The New York Times, 15 Ocak 2019. 116 Ibid. 
değerlendirilmiştir. ${ }^{117}$ Özellikle Türkiye-ABD ilişkilerinin gergin olduğu bir dönemde Suriye'de Türkiye ve $\mathrm{ABD}$ arasında bir askeri çatışmanın önlenmesine ilişkin konuları görüşürken Tillerson'un standart dışı olarak yalnız başına görüşmeyi gerçekleştirmesi ve çevirilerin Türkiye Dışişleri Bakanı Mevlüt Çavuşoğlu tarafından yapılması eleştirilmiştir. Bir ay sonra Trump tarafından aniden görevden alınan Tillerson'un çevirmensiz gerçekleştirdiği görüşme sonuçsuz kalmıştır. Tillerson'un yerine Dışişleri Bakanı olarak atanan Mike Pompeo'nun da Ekim 2018'de Kuzey Kore lideriyle kendi çevirmeni olmadan girdiği iki saat süren görüşmeden yanlış bir izlenimle ayrıldığı görülmüştür. Pompeo başarılı bir görüşme olduğunu söylerken, Kuzey Kore ABD’nin "gangstervari” baskılarına boyun eğmeyeceğini belirten resmi bir açıklama yayımlamıştır. ${ }^{118}$

Putin'le Temmuz 2018'de Helsinki'de baş başa bir görüşme gerçekleştiren Trump, çevirmeni Marina Gross dışında hiçbir Amerikalı görevliyi bu görüşmeye dahil etmemiştir. ${ }^{119}$ İki saat süren görüşmenin ardından düzenlenen ortak basın toplantısında da Putin'in söylemini benimsemiş ve ABD'de süregelen soruşturmayı hiçe sayarak Rusya’nın ABD seçimlerine müdahale etmesinin söz konusu bile olamayacağını söylemiştir. ${ }^{120}$ Bazı Senatörler, Trump-Putin görüşmesinin ayrıntılarını öğrenmek için çevirmen Marina Gross'u mahkemeye çağırma talebinde bulunmuştur. ${ }^{121}$ Ancak Cumhuriyetçi Senatörler ve Beyaz Saray'da görev yapmış çevirmenler de çevirmenin "sırdaş" olma vasfı ve mesleki etik kurallarını vurgulayarak bu talebe karşı çıkmıştır. ${ }^{122}$

ABD Basını, Trump’ın çevirmen Marina Gross'un notlarını aldığını ve Putin’le yapılan görüşmeyle ilgili kimseye bilgi vermemesi konusunda çevirmene "olağanüstü” baskı yaptığını iddia etmiştir. ${ }^{123}$ Trump’ın çevirmenlerinin notlarını saklamasının teamüllere aykırı olduğu, Ronald Reagan ve Richard Nixon gibi zaman zaman yabancı liderlerle baş başa görüşmelere giren ABD Başkanlarının bile bu görüşmeleri gizlice kaydetme, not tutma ve konuşulanların özet raporunu sunma yoluyla arşivlediği belirtilmektedir. ${ }^{124}$ Kritik uluslararası görüşmelerde not tutulmaması veya notların imha edilmesi karşı tarafın tezlerine karşı ABD’nin elini zayıflatmaktadır. ${ }^{125}$ Trump'ın bir ABD Başkanı olarak Rus liderle ne konuştuğunu Dışişleri Bakanlığı ve Beyaz Saray temsilcilerinden saklaması, ulusal çıkarlar lehine davranmadığı iddialarını doğurmuştur. ${ }^{126}$ Trump'ın çevirmeninin notlarını

117 Nicole Gaouette, “Tillerson breaks protocol by meeting Turkey's Erdogan without translator”, CNN, 15 Şubat 2018, https://edition.cnn.com/2018/02/15/politics/tillerson-erdogan-turkey-meeting-no-translator/index.html (Erişim Tarihi 5 Eylül 2019).

118 Nick Wadhams ve Jihye Lee, “Pompeo Faced Hard Bargain From Start of His Pyongyang Trip”, Bloomberg, 8 Ekim 2018, https://www.bloomberg.com/news/articles/2018-10-07/pompeo-faced-hard-bargain-from-the-start-of-hispyongyang-trip (Erişim Tarihi 5 Eylül 2019).

119 Nicole Gaouette ve Elise Labott, “Trump's Helsinki performance puts translator in the spotlight”, CNN, 19 Temmuz 2018, https://edition.cnn.com/2018/07/18/politics/trump-russian-translator-spotlight/index.html (Erişim Tarihi 5 Eylül 2019).

120 Baker, "Trump and Putin".

121 John Haltiwanger, "Meet Marina Gross, the interpreter who was the only other American in the room for Trump and Putin's 1-on-1 meeting in Helsinki”, Business Insider, 14 Ocak 2019.

122 Emily Cochrane, "Who Heard What Trump Said to Putin? Only One Other American", The New York Times, 19 Temmuz 2018.

123 Greg Miller, "Trump has concealed details of his face-to-face encounters with Putin from senior officials in administration”, The Washington Post, 13 Ocak 2019; Michelle Mark, "Trump reportedly hid records of his conversations with Putin from his own administration”, Business Insider, 12 Ocak 2019.

124 Baker, "Trump and Putin”; Cochrane, "Who Heard What Trump Said".

125 Cochrane, "Who Heard What Trump Said".

126 Baker, "Trump and Putin”; "Dışişleri Komisyonu Başkanının resmi duyurusu”, ABD Temsilciler Meclisi, 2019, https:// foreignaffairs.house.gov/2019/1/engel-statement-on-trump-putin-meetings (Erişim Tarihi 5 Eylül 2019). 
saklayarak Rus istihbarat örgütünün görüşmeyle ilgili uluslararası kamuoyunu yönlendirmesine izin verdiği iddia edilmektedir. ${ }^{127}$ Gizliliği savunanlarsa Başkan seçilmesinden bu yana Trump'in her sözünün bürokratlar tarafından çarpıtılarak basına sızdırıldığını, dolayısıyla Başkanın görüşmelerini gizli tutmasının doğal olduğunu düşünmektedir. ${ }^{128}$

Trump'ın Kuzey Kore lideri Kim Jong-un ile Nisan 2018'de Singapur'da yaptığı tarihi görüşmeye sadece çevirmeniyle katılması da merak uyandırmıştır. ${ }^{129}$ Görüşmenin ardından Trump ve Kim Jong-un, Kore yarımadasını nükleer silahlardan arındırma konusunda anlaşmaya vardıklarını ilan etmişlerdir. ${ }^{130}$ Ayrıca, Trump 1976 ve 2001 yıllarından bu yana süregelen ABD-Güney Kore ortak askeri tatbikatlarının sona erdirilmesine karar verdiğini açıklamıştır. Görüşmede Trump'n çevirmenliğini yapan ABD Dışişleri Bakanlığı Çeviri Bürosu şefi Yun Hyang Lee, uluslararası kamuoyunda soğukkanlılı̆ı̆ı koruyamayan iki "çılgın” lider olarak tanınan Trump ve Kim-Jongun arasındaki barışçı iletişime aracı olduğu için $\mathrm{ABD}$-Kuzey Kore tarihi görüşmesinin "görünmez kahramanı" ilan edilmiştir. ${ }^{131}$

Yun Hyang Lee, 2015 yılında verdiği bir röportajda diplomatik çeviride "Evet" ve "Hayır" gibi kesinlik içeren ifadelerin yerinin olmadığını, bunun yerine her zaman "kapıyı açık bırakan" ifadeler kullanılması gerektiğini söylemiştir. ${ }^{132}$ Dolayısıyla çevirmenler, liderler arasında yapılan gizli görüşmelerde yaptıkları müdahaleleri ve oynadıkları uzlaştırıcı rolleri baskılardan, etik veya yasal kısıtlamalardan ötürü açılklayamasalar da, hem "sırdaş" hem eşik bekçisi hem de arabulucu olarak aktif rol oynamaktadır. Trump'ın notlarını saklaması çevirmenlerin etkisinin az olduğunu göstermekten ziyade, Dışişleri Bakanının bile erişemediği çok kritik bilgilere erişebildiklerini ve liderin sırdaşı pozisyonunda olduklarını gösterir.

1985-1991 yılları arasında SSCB lideri ve Dışişleri Bakanı’nın çevirmeni olarak ABD-SSCB diplomatik müzakerelerinde görev almış olan Pavel Palazchenko da bu görüşü desteklemektedir. SSCB Dışişleri Bakanı Shevardnadze’nin Ronald Reagan ile baş başa görüşmesinden sonra kendisine Reagan'ın yaklaşımıyla ilgili izlenimini sorduğunu, daha sonra da özellikle ikili görüşmelerin ardından kişisel yorumlarını sormaya devam ettiğini belirtmiştir. ${ }^{133}$ Palazchenko’ya göre, Trump'ın Kuzey Kore ve Rusya gibi ABD ulusal güvenliği açısından kritik önemde olan devletlerin liderleriyle görüşmelerinde sadece çevirmenin bulunması konusunda ssrarcı olması, çevirmenlerin liderler ve diplomasi üzerindeki etkisinin incelenmesi açısından dikkat çekicidir. ${ }^{134}$

127 Jason Lemon, “Trump was 'aiding and abetting' Russian Intelligence by allegedly asking his interpreter to conceal notes, National Security Expert Says", Newsweek, 13 Ocak 2019.

128 Marc Thiessen, “Trump is surrounded by leakers. Why would he trust them with his Putin notes?”, The Washington Post, 15 Ocak 2019; Baker, “Trump and Putin”.

129 “Trump-Kim summit: Deciphering what happened in Singapore”, BBC, 13 Haziran 2018, https://www.bbc.com/ news/world-asia-44451587 (Erişim Tarihi 5 Eylül 2019).

130 Eli Meixler ve Mahita Gajanan, “Meet the 'Unsung Hero' Who Interpreted for President Trump During His 1-on-1 With Kim Jong Un”, TIME, 12 Haziran 2018.

131 Ibid.

132 Ibid.

133 Pavel Palazchenko, My Years with Gorbachev and Shevardnadze: The Memoir of a Soviet Interpreter, Pennsylvania, Penn State Press, 2010, s. 52-53.

134 Ilya Zhelgulev, "Like the failed summit before the Cuban Missile Crisis Long-time Soviet interpreter Pavel Palazhchenko puts the Trump-Putin meeting in historical context”, Meduza, 16 Temmuz 2018. 
Önceki bölümde belirtildiği gibi, diplomatik çevirmenler liderler arasında uzlaştırıcı bir rol oynayabilirler. Bunu günah keçisi olarak ya da kriz önleyici müdahalelerde bulunarak yapabilirler. Çevirmene genellikle kendi isteği dışında atfedilen "günah keçisi” rolü, çevirmenin görüşmede adeta farklı bir aktör gibi düşünüldüğü ve kriz ortamından çıkmak için baş sorumlu ilan edildiği durumlarda ortaya çıkar. Krizleri aşmak için liderler çevirmeni sorumlu tutarak karşı taraftan özür dilemek zorunda kalmadan kendilerini aklar ve iletişimi sürdürürler. Örneğin, NATO zirvesi sırasında yapılan bir görüşmede Trump, Türkiye Cumhurbaşkanı Erdoğan’a İsrail'de tutulan bir Türk vatandaşının serbest bırakılmasıyla ilgili destek vermeyi kabul etmiş ve karşılı̆̆ında Türkiye'de terör şüphesiyle tutulan Amerikalı rahip Andrew Brunson'un serbest bırakılmasını istemiştir. ${ }^{135}$ Türk liderin "Tamam, bakarız" şeklindeki yanıtı çevirmen tarafından "OK, I will look into it” şeklinde çevrilince Trump Amerikalı rahibin derhal serbest bırakılacağını sanmıştır. ${ }^{136}$ İzleyen süreçte Rahip Brunsson hapisten çıkarılıp ev hapsine alındığında Trump, Beyaz Saray’da basına verdiği bir röportajda Türk liderin kendisini kandırdığını iddia etmiş ve ardından Türkiye'ye karşı ekonomik ve siyasi yaptıım kararı almıştır. ${ }^{137}$ Türk tarafı Brunson'un serbest bırakılmasını pazarlık konusu etmediklerini beyan ettikten sonra yanlış anlaşılmanın çevirmen hatasından kaynaklandığı anlaşılmış ve ilişkilerdeki gerginlik azalmıştır. ${ }^{138}$

Çevirmenler, görüşmelerde tıkanıklığa yol açacak ifadelerin çevirisi sırasında kriz önleme amaçlı birtakım müdahaleler yapabilirler. ${ }^{139}$ Özellikle, müzakere eden tarafların belirsiz ve çok anlamlı ifadeler aracılığıyla birbirini yanlış yönlendirmesini ve farklı görüşleri şeytanlaştıran çatışmacı bir dil kullanmasını önlemeyi amaçlarlar. ${ }^{140}$ Diplomatik çevirmenlerin karşılaştı̆̆ı en büyük sorunlardan biri tarafların fanatizm ve görelilik sergileyen tutumları sonucu görüşmelerin çıkmaza girmesidir. ${ }^{141}$ Fanatizm, müzakereler sırasında "Ben haklıyım, sen haksızsın" yaklaşımıyla uzlaşmayı zorlaştırırken görelilik de "Herkes kendine göre haklı” tutumuyla ortak çözüm zemini hazırlanmasını zorlaştırır. ${ }^{142}$ Çevirmen bu tür tutumları fark ettiğinde görüşmelerin çıkmaza girmesini önlemek için bazı ifadeleri sansürleme veya değiştirme yoluna gidebilir.

Örneğin, 16 Mayıs 2017 tarihinde Washington'da düzenlenen ABD-Türkiye ortak basın toplantısı sırasında çevirmen, Türk liderin konuşmasındaki "YPG/PYD terör örgütü” ifadesini İngilizce’ye "terör örgütü” ifadesini çıkararak çevirmiştir. ${ }^{143}$ ABD’nin YPG ve PYD Kürt örgütlerini IŞID’e karşı desteklemesi, iki NATO müttefiki arasında derin bir krize sebep olduğundan, çevirmenin bu konuyu gündem dışına itmesi kriz önleyici müdahaleye bir örnek olarak görülebilir. Çevirmen, aktif şekilde eşik bekçiliği yaparak liderleri çıkmaza götürecek ifadeleri sansürlemeyi tercih etmiştir. İzleyen bölüm, çevirmenlerin eşik bekçiliği yaparak Trump’ın uluslararası imajını etkileyecek müdahalelerde bulunduğunu ve adeta bir “kamu diplomasisi filtresi”ne dönüştüğünü göstermektedir.

135 Martin Chulov, “Trump misunderstanding over prisoner fuelled lira crisis - Ankara sources”, The Guardian, 13 Ağustos 2018.

136 Ibid.

137 Alex Lockie, “A simple misunderstanding between Trump and Erdogan may have tanked Turkey's economy”, BusinessInsider, 14 Ağustos 2018.

138 “Cumhurbaşkanı Erdoğan: Brunson konusunu pazarlık yapmadık”, HaberTürk, 29 Temmuz 2018.

139 Benoit Girardin, "Language: setting the stage for diplomacy”, Jovan Kurbalija and Hannah Slavik (der.), Language and Diplomacy, Malta, Diploprojects, 2001, s. 145-146, https://www.diplomacy.edu/resources/general/language-settingstage (Erişim Tarihi 5 Eylül 2019).

140 Ibid.

141 Ibid.

142 Ibid.

143 “Erdoğan-Trump görüşmesinde tercüman skandalı”, Hürriyet, 17 Mayıs 2017. 


\section{Trump Dili ve Diplomatik Çeviri}

Trump ve çeviri (translation) kelimelerinin birleşiminden meydana gelen “Trumpslation” sözcügü, geleneksel diplomasi diline alışmış çevirmenlerin Başkan Trump’ın nevi şahsına münhasır üslubunu çevirirken büyük zorluk çektiğini vurgulamak için icat edilmiştir. ${ }^{144}$ Çevirmenlerin iletişim filtresi rolü Trump döneminde daha belirgin hale gelmiştir. Çoğu çevirmen eşik bekçiliği yaparak, Trump’ın söylemlerini laf kalabalığından, belirsizlikten ve diplomatik dile yabancı olan -argo, ırkçı ve cinsiyetçitabirlerden arındırma yolunu seçmektedir. Böylelikle, çevirmenler hem liderler arası görüşmeleri hem de kamu diplomasisini kolaylaştırma görevini yerine getirmektedirler.

Fransız çevirmen Bérengère Viennot, “Trump'ın dili” adlı kitabında, ABD Başkanı Trump’ı önceki Başkan Obama ile karşılaştırarak Trump'ın söylemlerini gayriresmi, kaba ve ifade yoksunu olarak değerlendirmiştir. ${ }^{145}$ Örneğin, Trump The New York Times gazetesine verdiği bir röportajda tam 48 defa "great" sıfatını kullanmış ve demeçlerinde sınırlı sayıda basit sıfata - tremendous, incredible, strong, tough, good, bad gibi- yer vermiştir. ${ }^{146}$ Trump'ın diline yönelik eleştirilerden bir diğeri de belirsizliktir. Trump, sıklıkla kendi söyledikleriyle çelişen muğlak ifadeler kullanmaktadır. Diplomaside söylenen ve söylenmeyen, dolaylı ve dolaysız tüm sözcükler ince ince hesaplandığı için konuşmacı da çevirmen de olası belirsizlikleri ve yanlış anlaşılmaları önlemek için azami gayret sarf eder. Ancak Trump’ın sıklıkla kullandığı bölük pörçük ve nereye bağlanacağı belli olmayan ifadeler, düşük cümleler ve konudan konuya atlama eğilimi belirsizliği ciddi ölçüde artırmaktadır. ${ }^{147}$

Trump'ın çekinmeden kullandığı alaycı ve rencide edici ifadeler de çevirmenleri zorlayan bir konu olarak öne çıkmaktadır. Örneğin, Kuzey Kore liderine atfen kullandığı küçümseyici ve alaycı "küçük füze adam" (little rocket man) tabiri önceki liderlerden farklı olarak Trump’n cinsiyetçi bir dil kullanmaktan kaçınmadığını göstermektedir. ${ }^{148}$ Japon çevirmen Tsuruta siyaseten doğru olmayan dilin aktarılmaması gerektiğini kabul eder ancak orijinal konuşma siyaseten doğru ifadeler içermiyorsa, "Dili steril hale getirmek bizim işimiz mi?" diye sorarak çevirmenin karşılaştığı ikilemi dile getirmektedir. ${ }^{149}$ Bazı çevirmenler "konuşmacı ... düpedüz yalancı bile olsa yapmanız gereken onun dediklerini aynen çevirmektir... Kendi duygularınızı bir tarafa bırakmalısınız ve konuşmacının hüviyetine bürünmelisiniz” demektedir. ${ }^{150} \mathrm{Bu}$ görüşe göre, Trump bu standart dişı üslubu bilinçli olarak seçmiştir. Bu nedenle kullandığı ifadeleri standartlara uygun hale getirmek hatalıdır. Diplomasi dilinden farklı bir dil kullanarak Trump seçmen kitlesine "daha samimi" ve "Amerikalı" bir tutum sergilemeyi amaçlamaktadır. ${ }^{151}$ Karşıt görüşe göre çevirmen liderlerin söylemlerini resmiyet, açıklık, ikna edicilik, mantığa ve nezaket kurallarına uygunluk açısından yeniden şekillendirmelidir.

144 Severine Hubscher-Davidson, “Trumpslation: why Donald Trump's words give translators so much trouble”, The Conversation, 7 Ağustos 2017, https: //theconversation.com/trumpslation-why-donald-trumps-words-give-translatorsso-much-trouble-81968 (Erişim Tarihi 5 Eylül 2019).

145 Bérengère Viennot, "Pour les traducteurs, Trump est un casse-tête inédit et désolant", Slate France, 14 Aralık 2016, https://www.slate.fr/story/131087/traduire-trump-mourir-un-peu (Erişim Tarihi 5 Eylül 2019).

146 Ibid; Begüm Dönmez Ersöz, “Interpreting the new US President: Trumpslation”, Hürriyet Daily News, 28 Ocak 2017.

147 Chloe Farand, “Donald Trump confuses French translators with mixed-up speeches”, Independent, 21 Ocak 2017.

148 John Riedl, "On Ethics for Translators: The Elephant in the Room”, Newsletter of The Slavic Languages Division, Cilt 27, No 3, 2018, 18-20, http://www.ata-divisions.org/SLD/wp-content/uploads/2018/09/SlavFile-2018-3-Summer. pdf (Erişim Tarihi 5 Eylül 2019).

149 Chikako Tsuruta, “Trust in Trump in translation”, Contemporary French and Francophone Studies, Cilt 21, No 5, 2017 , s. 595.

150 Torikai, "Voices of the invisible presence".

151 Viennot, "Pour les traducteurs". 
Konuşmacı dinleyenleri yanlış yönlendiren ifadeler kullandığında çevirmenin müdahale ederek bunu engellemesi gerekir. ${ }^{152}$

Örneğin, Hindistan'daki en yüksek tirajlı gazetelerinden Dainik Bhaskar'da Trump'la ilgili haberleri Hintçe'ye çeviren Rajesh Pandey, Trump'ın mesajlarını Hint halkının alıştığı siyasi retoriğe uygun şekilde ve en yalın haliyle aktarmaya gayret ettiğini ifade etmiştir. ${ }^{153}$ "Eğer Trump'ın ismini cümleden çıkarırsanız, Trump'in seçilmesi sırasında kullandığımız dil pekâlâ Başbakan Modi'ye de ait olabilirdi. Her ikisi de ulusu ve ulusal gururun büyüklügünü vurguluyor.” diyerek Trump dilinin farklılığını ön plana çıkarmak yerine liderlerin söylemleri arasında uzlaştırıcı bir rol oynamayı tercih ettiğini vurgulamıştır. ${ }^{154}$ Rus çevirmenler de Trump'ın “çocukça” bulunan ifadelerini değiştirerek sanki Rus lider Putin konuşuyormuş gibi algılanacak şekilde "düzelttiklerini” açıklamıştır. ${ }^{155}$

Uluslararası arenada çevirmenler arasında Trump'ın canlı yayında verdiği demeçleri çevirirken olduğu gibi mi yoksa "bir Başkana yaraşan bir dile” mi çevrilmesi gerektiği tartışması sürmektedir. ${ }^{156}$ Çevirmenler, özellikle Trump’ın Başkanlık seçim kampanyası sırasında kullandığı cinsiyetçi ve ırkçı ifadeleri çevirirken büyük sıkıntı çektiklerini belirtmişlerdir. ${ }^{157}$ Trump’ın "bigly” gibi uydurma ve "nasty woman" gibi cinsiyetçi, kaba ve ahlak dışı bulunma riski taşıyan ifadeleri, çevirmenleri daha sık eşik bekçiliği yapmaya sevk etmektedir. ${ }^{158}$ Çevirmenlerin Trump'ın kullandığı rencide edici, ırkçı ve cinsiyetçi ifadeleri sansürledikleri veya yumuşattıkları görülmüştür. ${ }^{159}$

Örneğin, Trump’ın söz kesme alışkanlığının parçası olarak kullandığı ve Trump diliyle özdeşleşen "Yanlış!” (Wrong!) ifadesi, İspanyolca diline "Bu doğru değil” (Eso no es correcto) şeklinde çevrilerek yumuşatılmıştır. ${ }^{160}$ Ayrıca, Trump’ın Meksikalılara atfen kullandığı İngilizce ve İspanyolca karması uydurma bir deyiş olan "bad hombres" ifadesi, İspanyolcaya "kötü adamlar" (hombres malos) olarak çevrilince, ırkçı bir ifade olmaktan çıkarak "çocuksu" bir ifadeye dönüşmüştür. ${ }^{161}$ Benzer şekilde, Trump'ın Latino kökenli ABD vatandaşlarını rencide eden "Bayan Temizlikçi” (Miss Housekeeping) tabirinde gizli olan ayrımcılık ve irkçllık vurgusu tabir Rusça’ya çevrildiğinde kaybolmuştur. ${ }^{162}$ Seul TV kanalı Munhwa için 2016 Başkanlık seçimlerini Korece'ye çeviren Ha Yeon Kim, Trump’ın diğer adaylar için kullandığı gayriresmi dile çok şaşırdığını belirterek "Doğrudan dediğini çeviremezdim, eğer çevirseydim, çok saldırgan olurdu” demiştir. "Kısalttım, mesaj aynı oldu ama daha resmi bir hal aldı” diyerek metne müdahalede bulunduğunu itiraf etmiştir. ${ }^{163}$ Kısaca, çevirmenlerin iletişim filtresi ve eşik bekçisi rolleriyle Trump döneminde kamu diplomasisine de etkide bulunduğu görülmektedir.

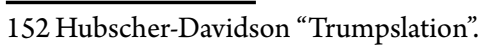

153 Ibid.

154 Ibid.

155 Ibid.

156 Daniel Morales, “Japanese translators forced to grab the Trump bull by the horns”, The Japan Times, 14 Kasım 2016.

157 Ibid.

158 David Leonhardt ve Ian Prasad Philbrick, “Donald Trump's Racism: The Definitive List”, The NewYork Times, 15 Ocak 2018.

159 Morales, "Japanese translators".

160 Lila McLellan, “Interpreters Say It’s Nearly ‘Impossible’ To Translate Donald Trump’s Rhetoric Into Other Languages”, Huffington Post, 27 Ekim 2016, https://www.huffpost.com/entry/donald-trump-rhetoric-translation_n_5810de0ae4b $001 \mathrm{e} 247 \mathrm{dfb} 2 \mathrm{f} 8$ (Erişim Tarihi 5 Eylül 2019).

161 McLellan, "Interpreters Say"

162 Riedl, "On Ethics for Translators".

163 Joseph Hincks, “Translating Trump and Kim: Spare a Thought for the Interpreters at the June 12 Summit”, TIME, 11 Haziran 2018. 


\section{Sonuç}

$\mathrm{Bu}$ çalışma, çevirmenlerin diplomasideki etkinliğini mercek altına alarak diplomatik çevirmenlerin dış ilişkilerde kilit görevler üstlendiklerini ortaya koymaktadır. Çalışmada incelenen örnekler, doğru ve etkin şekilde yapıldığında çevirinin kriz önleme ve tarafları uzlaştırma etkisi olduğu gibi, hatalı ve eksik çevirinin de uluslararası ilişkilerde ciddi krizlere yol açabileceğini vurgulamaktadır. Çevirmenin pasif, görünmeyen ve yalnızca asilin uzantısı olan bir vekil olarak ele alınması, çevirmenlerin diplomaside oynadığı çeşitli rol ve işlevlerin gözden kaçmasına yol açmaktadır. Özellikle diplomasi dilinin ve teamüllerinin sistematik olarak devre dışı bırakıldığı bir dönemde çevirmenlerin liderlerin söylemlerine aktif müdahalelerde bulunarak diplomaside başlı başına bir aktör konumuna geldiği görülmektedir. Diplomatlar devre dışı bırakıldığında çevirmenler, geleneksel olarak diplomatların başat rol oynadığı, iki devlet arasında doğrudan iletişim ağı kurmak ve arabuluculuk gibi temel diplomasi etkinliklerinin uygulanmasında etkin rol oynayabilmekte ve bir çeşit fiili diplomatlık (de facto diplomat) görevi üstlenmektedir. ${ }^{164}$

Çevirmenler, diplomasiye "iletişim filtresi" ve "uzlaştırma" bağlamında iki temel katkı sağlamaktadır. Trump dönemine ait incelenen örnekler, çevirmenlerin eşik bekçiliği, günah keçisi olma ve kriz önleme gibi hem iletişim filtresi hem de uzlaştırıcı olarak dış ilişkilerde etkin rol oynamak için daha geniş bir müdahale alanı bulduğunu göstermektedir. Özellikle Trump'ın Putin ve Kim Jongun ile baş başa görüşmelerine sadece çevirmeniyle katılmış olması ve görüşmelerin büyük ölçüde iki tarafın uzlaşmasıyla sonuçlanması, Trump döneminde çevirmenlerin hareket alanının geçmişe göre genişlediğine ve bu zorlu görüşmelerde önemli görevler yerine getirebildiklerine kanıt teşkil etmektedir.

Ayrıca, çevirmenler önemli bir "kamu diplomasisi filtresi” işlevi görmektedir. Bu işlev özellikle Trump' ın söylemlerinin uluslararası kamuoyuna aktarılmasında ön plana çıkmaktadır. Birçok çevirmen, Trump gibi diplomasi dilinden uzaklaşan bir liderin mesajlarını diplomatik dile uygun hale getirerek söyleme müdahalede bulunmaktadır. Bu sayede dil, kültür ve vizyon farklılıklarından doğacak yanlış anlaşılmaların önüne geçerek liderlerin uluslararası imajını doğrudan etkilemektedirler. Sonuç olarak, tarihin çeşitli dönemlerinde diplomaside etkin olan ve diplomasinin kurumsallaşmasıyla diplomatların gerisine itilmiş olan çevirmenlerin, günümüzdeki diplomasi karşıtı uygulamaların sıklaşması nedeniyle diplomaside yeniden etkin roller üstlenmekte oldukları görülmektedir. Çevirmenlerin diplomaside sorumluluğunun artması, diplomatik dilin korunması ve kültürlerarası iletişimin sağlıklı bir zeminde devamının sağlanması açısından olumlu bir gelişmedir. Ancak, uzun vadede çevirmenlerin diplomatların yerini alan değil, onları tamamlayan aktörler olarak görülmesi, diplomasinin geleceği açısından isabetli olacaktır.

164 Graham, "The Strange, High-Pressure Work”. 